\title{
The Precambrian-Cambrian biosphere (r)evolution: Insights from the Chinese Yangtze Platform
}

\author{
OldŘICH FATKa, Michael Steiner, Bernd Weber \& MaOyan ZhU
}

The PC-C boundary interval represents one of the critical phases in the evolution of life. Any outside observer considering the approximately 4500-million-year history of our planet would likely choose the $150 \mathrm{Ma}$ time interval between 650 and $500 \mathrm{Ma}$ as one of the most dramatic periods in Earth history. This period connects the Proterozoic and Phanerozoic Eons with its boundary at $542 \mathrm{Ma}$. It includes the Ediacaran ( $\mathrm{ca}$ 630-542 Ma) and the Cambrian (542-493 Ma) periods. The Ediacaran, in particular, is characterized by concurrent profound changes in global tectonics, possibly the largest climatic deviation from the steady-state mean global temperature since the Archean (popularized by the "Snowball Earth" concept; Hoffman \& Schrag 2000), the first evidence leading to the possibly "explosive" (on a geological scale) but indisputably largest evolutionary radiation event of the biosphere, and a significant increase of free atmospheric and oceanic oxygen. The subsequent Cambrian time interval largely records the gradual establishment of a newly acquired ecologic stability, the beginning of the metazoan conquest of Earth's surface environment, and a profound rearrangement in the chemical composition of Earth's atmosphere and oceans.

The South China Craton (Yangtze Craton) represents one of the smaller East Gonwanan palaeocontinents (Vaughan \& Pankhurst 2008). It apparently formed part of the northern Rodinia margin in low southern latitudes and had largely been covered by a stable shallow-marine platform by ca 800 Ma (Powell \& Pisarevsky 2002, Veevers 2003). Subsequent sedimentation was mostly counterbalanced by tectonic subsidence and thus preserves a sedimentary record ranging with only minor hiatuses from the Proterozoic into the Triassic. The succession includes a thick, well-exposed PC-C boundary interval. The Yangtze palaeocontinent rifted off Rodinia at approximately $750 \mathrm{Ma}$ and became incorporated into southeastern Palaeo-Asia during the Early Triassic. Since then, it underwent only minor tectonic and thermal modification.

Although shallow-water sequences of the PC-C interval have been described from several other Precambrian cratons of West-Gondwana (e.g. Namibia), East-Gondwana (e.g. Antarctica, Australia) as well as Baltica and Siberia, the Yangtze Platform offers a unique opportunity for understanding the drivers and mechanisms of the PC-C biosphere (r)evolution for the following reasons:

(1) The sedimentary record covers the entire time interval from the Ediacaran to the middle Cambrian, whereas the records on comparable platforms such as North China, Australia, or Antarctica include larger stratigraphic hiatuses:

(3) The facies diversity is associated with a broad range of laterally time-equivalent lithologies, including carbonates, phosphorites, cherts, black shales, and minor tuffs.

(2) The region of platform sedimentation is large ( ca 1.8 million $\mathrm{km}^{2}$ ) and spans a wide facies spectrum, ranging from erosional and evaporitic regimes over widespread shallow-water marine environments to shelf-edge (Lu et al. 2012) and deep-water continental slope settings. Perhaps uniquely worldwide, these settings can still be related to each other in their original spatial context.

(4) Tectonic deformation and thermal overprinting have been minor, except at the platform margins, near fault and collisional zones.

(5) The strata are richly fossiliferous, highlighted by several exceptional fossil Lagerstätten. The fossil record of the basal Cambrian strata of the Yangtze Platform demonstrates the phenomenon of the Terreneuvian bio-radiation.

The fossil Lagerstätten include the still disputed occurrence of Ediacaran eggs and embryos from the Weng' an locality in Guizhou Province (e.g. Xiao et al. 1998, Yin et al. 2012; but see Huldtgren et al. 2011), diverse acritarch assemblages (Liu et al. 2012b), and the unique macro-fossils from the latest Ediacaran siliciclastic shelf deposits of Gaojiashan, southern Shaanxi Province (e.g. Hua et al. 2009).

The Cambrian strata of the Yangtze Platform include the famous Burgess Shale-type fossil associations of the Chengjiang fossil Lagerstätte with exceptional soft-bodied preservations (Cambrian Stage 3, ca 525 Ma: e.g. Hou et al. 2004, Forchielli et al. 2012), the Kaili region (Cambrian Stage 5, ca 510 Ma: Zhao et al. 1996), the newly discovered Guanshan fossil assemblage (Wulongqing Fm.; Cambrian Stage 4: e.g. Hu et al. 2010, 2012; Liu et al. 2012a; Steiner et al. 2012; Weber et al. 2012) and the roughly time-equivalent Balang fossil assemblage (Peng et al. 2012). Other types of exceptional basal Cambrian fossil Lagerstätten yielded phosphatized Orsten-type organisms 


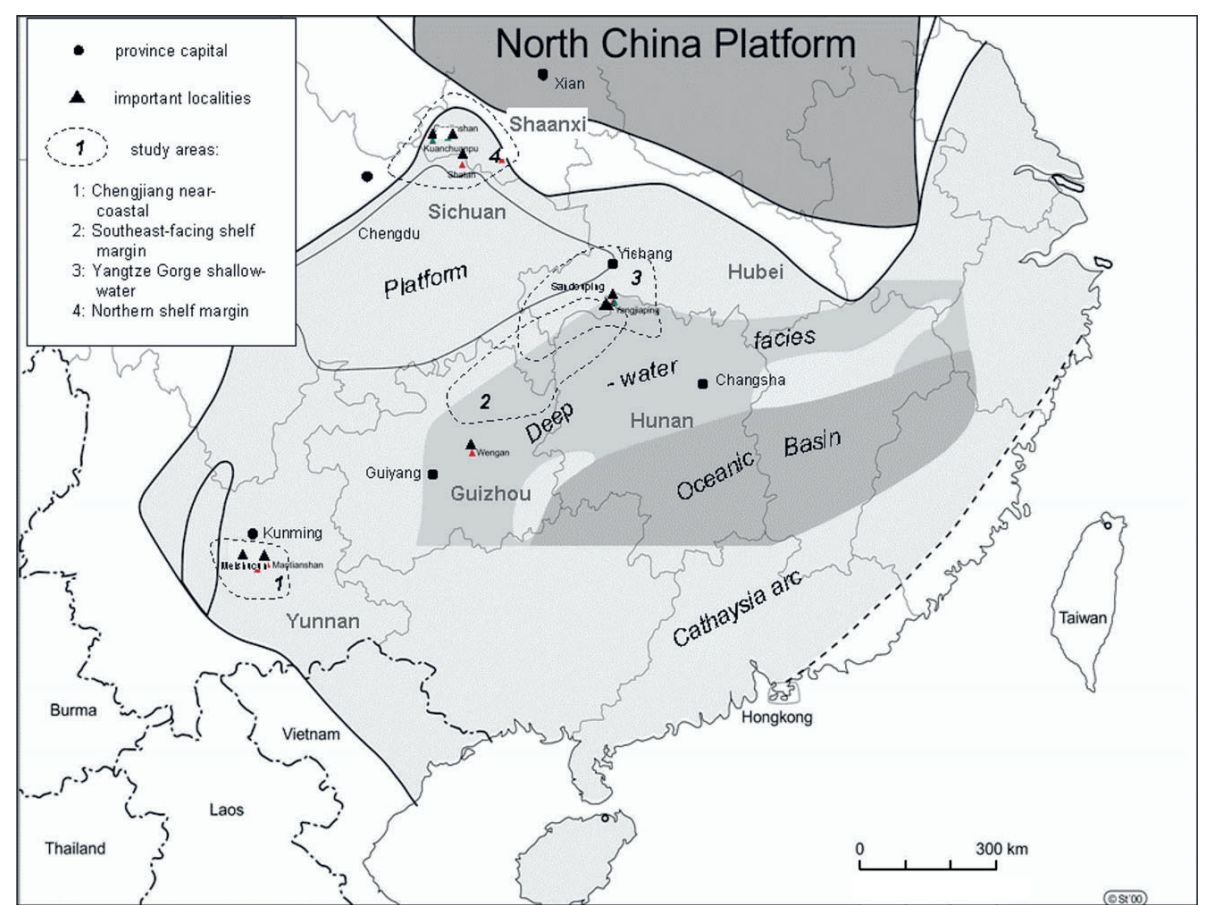

Figure 1. Geological overview map of South China, highlighting the study areas on the Yangtze Platform, most relevant locations, and principal facies belts (modified after Steiner et al. 2007).

(arthropods, eggs, embryos, cnidarians, algae, etc., from several other localities), exceptional trilobite assemblages (Dai \& Zhang 2012), and the rich small shelly fossil assemblages, widely distributed in the basal Cambrian of the entire Yangtze Platform (ca 540-520 Ma: e.g. Steiner et al. 2007, Li et al. 2012). Rencently, Sundberg et al. (2011) proposed the Wuliu-Zengjiayan section situated in the Guizhou Province as the GSSP for Cambrian Stage 5. The biostratigraphic zonation and chronostratigraphic subdivision of the Cambrian system in China and its correlation on a global scale are still disputed in many details (e.g. Peng \& Babcock 2011).

In September 2000, a bilateral Sino-German research group was founded, and a first bundle of palaeobiological, geological and geochemical research projects with a multidisciplinary approach started to operate in August 2001 and lasted until summer 2004 to investigate the causes, dimensions, and sequence of the PC-C bio-radiation event. The results of this initial research group revealed the complexity of the paradox of an apparently sudden diversification of life. It became obvious that only a truly multidisciplinary research approach is able to tackle the various reasons for the largest increase in organismic disparity. Thus, a Sino-German Priority Research Project (DFG-Forschergruppe FOR 736) with 16 Chinese and German sub-projects covering geological, geochemical, and palaeobiological topics was designed and came into action in January 2008 for the duration of 6 years. The individual projects are bilaterally financed via different stages of research funding by NSFC (China) and DFG (Germany) and complemented by various scholarships from the DAAD,
Chinese Scholarship Council, and Alexander von Humboldt Foundation. The FOR 736 summer school was established as an important instrument of scientific communication and study for the mostly young participants of international cooperation projects. Within the scope of this activity, the summer school studied the important and classical sedimentary successions of the Barrandian and Saxo-Thuringian micro-continents in June 2010 (Figure 2). Inspired by the achievements of geoscientists dealing with the early Palaeozoic of Bohemia, the research group decided to issue a volume in the Bulletin of Geosciences with contributions from the joint Sino-German Priority Project FOR 736.

In the present volume, a selection of 11 contributions by members of the research group with a focus on relevant sub-projects of FOR 736 is published, primarily illustrating palaeobiological research topics of the group.

One focus point of this special issue is the documentation of the diversity of the newly discovered Cambrian Stage 4 Guanshan fossil Lagerstätte, which is remarkable because it proves that soft-tissue preservation is possible in a rapid depositional environment with sufficient oxygenation and at a high bioturbation rate. The paper by Weber $e t$ al. (2012) describes and illustrates the diverse trace fossil communities of Guanshan Community, displaying different styles of sediment exploitation.

Hu et al. (2012) and Steiner et al. (2012) present new palaeontological data on the diversity of priapulid worms and lobopodians of this fauna. They describe three new taxa of palaeoscolecidans, one species of a corynetiid priapulid, and a new species of the enigmatic lobopodian Hallucigenia. This further illustrates that the diversity of 


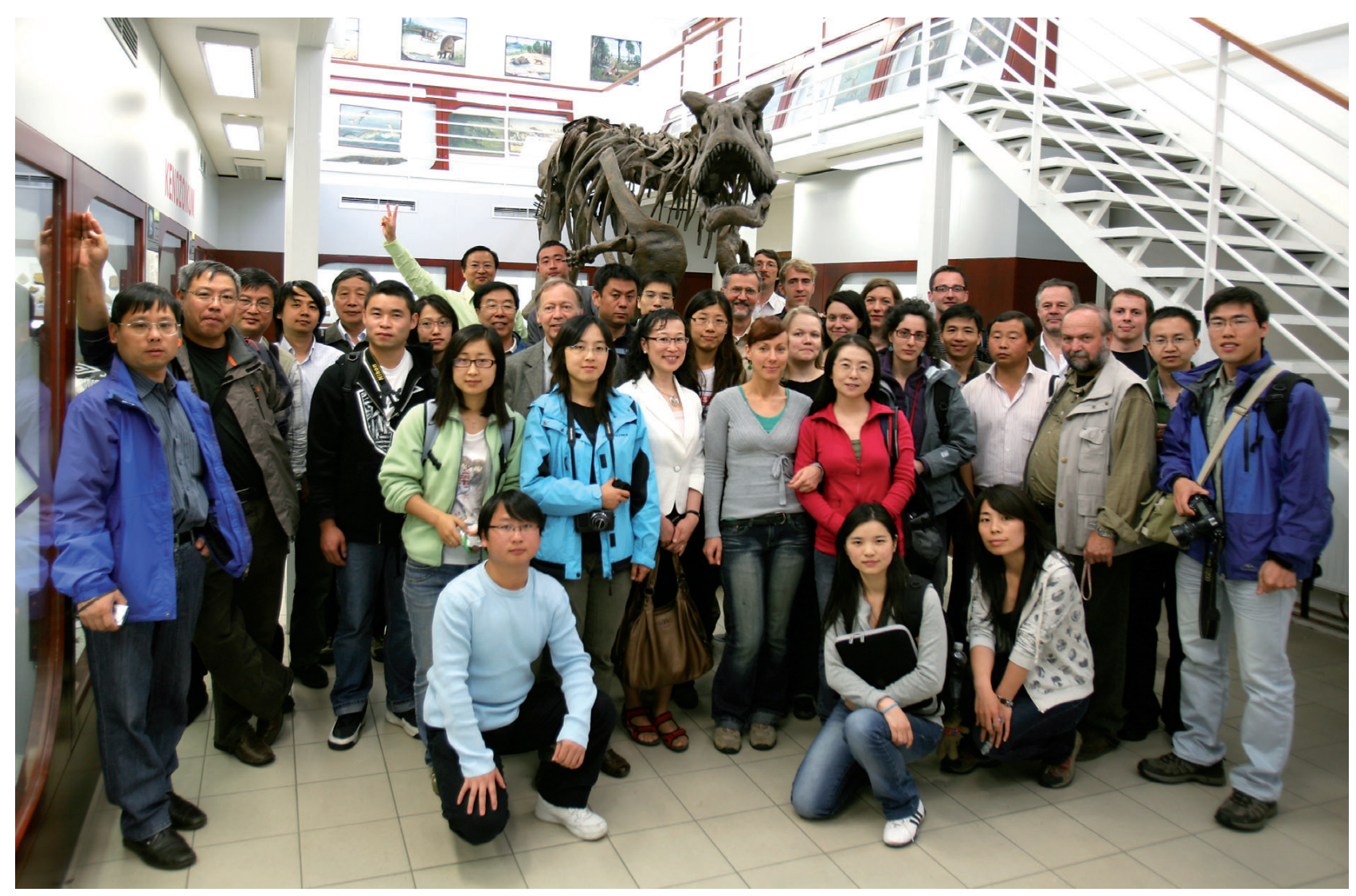

Figure 2. The members of the Sino-German research group during the summer school field trip to Bohemia in June 2010 in the entrance hall of the Chlupác Museum of the Charles University in Prague.

ecdysozoan clades increased dramatically toward the end of the Cambrian bioradiation event.

Liu et al. (2012a) describe a new occurrence of the Guanshan fossil assemblage from the Huize County of eastern Yunnan, China. This new fossil occurrence indicates that soft-tissue preservation was distributed in a wide area of at least approximately $80 \times 80 \mathrm{~km}$ during the Cambrian Stage 4 and it proves high potential for further explorations on fossil Lagerstätten.

Forchielli et al. (2012) also partially contribute to the study of the taphonomy of the Guanshan fossil Lagerstätte. They mostly discuss the preservational traits of sponges with originally siliceous spicules from both the similarly preserved Chengjiang and Guanshan fossil Lagerstätten to understand the timing and extent of iron mineral replacements of fossil occurrences with soft-tissue preservation.

Another article by Peng et al. (2012) describes the well-preserved new species Naraoia taijiangensis sp. nov. from the Balang Formation of Guizhou Province (China) that also contains the trilobite Redlichia and is roughly time-equivalent with the Wulongqing Fm. of Yunnan hosting the Guanshan Biota.

Dai \& Zhang (2012) document the ontogeny of the trilobite Estaingia sinensis from the slightly older Shuijingtuo
Fm. of Changyang County, Hubei Province (China). Besides including information on the ontogeny of the trilobite, this paper documents the similarity in redlichiid trilobite faunas of this period between South China and Australia.

Li et al. (2012) also describe skeletal remains of different ontogenetic stages of the eodiscoid trilobite Hupeidiscus orientalis from the Shuijingtuo Fm., but from a region in a marginal platform setting of southern Shaanxi Province (China). Structural data of the three-dimensionally preserved skeletal material prove that the form taxon Mongolitubulus is at least partially derived from eodiscoid trilobites such as Hupeidiscus orientalis.

Yin \& Zhu (2012) discuss differently ornamented spheroidal microfossils of the Ediacaran Weng' an fossil Lagerstätte of the Doushantuo Fm. as egg stages and blastula stages of metazoans. Recent discussions on the origin and assignment of these spheroidal microfossils underline the importance of various fossil Lagerstätten of Doushantuo Fm. in South China. Therefore, a detailed discussion of the chronostratigraphical framework and the international correlation of this formation is greatly needed. Lu et al. (2012) present new carbon isotope and sequence stratigraphy data of the stratotype section of the Doushantuo Fm. supporting a more solid correlation of this rock unit. 
In addition, Liu et al. (2012b) present new fossil data of well-preserved acritarch assemblages from the classical sections of the Doushantuo Fm. in the Yangtze Gorge region. They propose that the genus Ceratosphaeridium, which has already been reported from the Ediacaran of South Australia, may possibly support inter-continental correlation.

\section{References}

DAI, T. \& ZHANG, X.L. 2012. Ontogeny of the trilobite Estaingia sinensis (Chang) from the lower Cambrian of South China. Bulletin of Geosciences 87(1), 151-158.

DOI 10.3140/bull.geosci.1218

Forchielli, A., Steiner, M., Hu, S.X. \& Keupp, H. 2012. Taphonomy of Cambrian (Stage 3/4) sponges from Yunnan (South China). Bulletin of Geosciences 87(1), 133-142. DOI 10.3140/bull.geosci.1225

Hoffman, P.F. \& SchraG, D.P. 2000. Snowball Earth. Scientific American 282, 68-75. DOI 10.1038/scientificamerican0100-68

Hou, X.G., Aldridge, R.J., Bergström, J., Siveter, David J., Siveter, Derek J. \& Feng, X.H. 2004. The Cambrian fossils of Chengjiang, China: The flowering of early animal life. 248 pp. Blackwell Publishing, Malden \& Oxford. DOI 10.1002/9780470999950

Hu, S.X., Steiner, M., Zhu, M.Y., Luo, H., Forchielli, A., Keupp, H., Zhao, F.C. \& Liu, Q. 2012. A new priapulid assemblage from the early Cambrian Guanshan fossil Lagerstätte of SW China. Bulletin of Geosciences 87(1), 93-106. DOI 10.3140/bull.geosci.1238

Hu, S.X., Zhu, M.Y., Steiner, M., Luo, H.L., Zhao, F.C. \& LiU, Q. 2010. Biodiversity and taphonomy of the early Cambrian Guanshan biota, eastern Yunnan. Science China Earth Sciences 53(12), 1765-1773. DOI 10.1007/s11430-010-4086-9

Hua, H., CHEN, Z. \& YuAN, X.L. 2009. The advent of mineralized skeletons in Neoproterozoic Metazoa - new fossil evidence from the Gaojiashan Fauna. Geological Journal 42(3-4), 263-279. DOI 10.1002/gj.1077

Huldtgren, T., Cunningham, J.A., Yin, C.Y., Stampanoni, M., Marone, F., Donoghue, P.C.J. \& Bengtson, S. 2011. Fossilized Nuclei and Germination Structures Identify Ediacaran "Animal Embryos" as Encysting Protists. Science 334(6063), 1696-1699. DOI 10.1126/science.1209537

Li, G.X., STeiner, M., Zhu, M.Y. \& ZhaO, X. 2012. Early Cambrian eodiscoid trilobite Hupeidiscus orientalis from South China: ontogeny and implications for affinities of Mongolitubulus-like sclerites. Bulletin of Geosciences 87(1), 159-169. DOI 10.3140/bull.geosci.1224

Liu, J.N., Ou, Q., Han, J., Zhang, Z.F., He, T.J., Yao, X.Y., Fu, D.J. \& Shu, D. 2012. New occurence of the Cambrian (Stage 4, Series 2) Guanshan Biota in Huize, Yunnan, South China. Bulletin of Geosciences 87(1), 125-132.

DOI 10.3140/bull.geosci.1229

Liu, P.J., Yin, C.Y., Chen, S.M., TANG, F. \& GaO, L.Z. 2012. Discovery of Ceratosphaeridium (Acritarcha) from the Ediacaran
Doushantuo Formation in Yangtze Gorges, South China and its biostratigraphic implication. Bulletin of Geosciences 87(1), 195-200. DOI 10.3140/bull.geosci.1223

Lu, M., Zhu, M.Y. \& Zнао, F.C. 2012. Revisiting the Tianjiayuanzi section - the stratotype section of the Ediacaran Doushantuo Formation, Yangtze Gorges, South China. Bulletin of Geosciences 87(1), 183-194. DOI 10.3140/bull.geosci.1227

Peng, S. \& BABCOCK, L.E. 2011. Continuing progress on chronostratigraphic subdivision of the Cambrian System. Bulletin of Geosciences 86(3), 391-396. DOI 10.3140/bull.geosci.1273

Peng, J., Zhao, Z.L. \& Sun, H.J. 2012. Discovery and significance of Naraoia from the Qiandongian (lower Cambrian) Balang Formation, Eastern Guizhou, South China. Bulletin of Geosciences 87(1), 143-150. DOI 10.3140/bull.geosci.1231

Powell, C.M.A. \& Pisarevsky, S.A. 2002. Late Proterozoic assembly of East Gondwana. Geology 30, 3-6. DOI 10.1130/0091-7613(2002)030<0003:LNAOEG >2.0.CO;2

Steiner, M., Hu, S.X., Liu, J. \& Keupp, H. 2012. A new species of Hallucigenia from the Cambrian Stage 4 Wulongqing Formation of Yunnan (South China) and the structure of sclerites in lobopodians. Bulletin of Geosciences 87(1), 107-124. DOI 10.3140/bull.geosci.1280

Steiner, M., Li, G.X., Qian, Y., Zhu, M.Y. \& Erdtmann, B.-D. 2007. Neoproterozoic to early Cambrian small shelly fossil assemblages and a revised biostratigraphic correlation of the Yangtze Platform (China). Palaeogeography, Palaeoclimatology, Palaeoecology 254, 67-99.

DOI 10.1016/j.palaeo.2007.03.046

Sundberg, F.A., Zhao, Y.L., Yuan, J.L. \& Lin, J.P. 2011. Detailed trilobite biostratigraphy across the proposed GSSP for Stage 5 ("Middle Cambrian" boundary) at the WuliuZengjiayan section, Guizhou, China. Bulletin of Geosciences 86(3), 423-464. DOI 10.3140/bull.geosci.1211

VeEvers, J.J. 2003. Pan-African is Pan-Gondwanaland: Oblique convergence drives rotation during 650-500 Ma assembly. Geology 31, 501-504. DOI 10.1130/0091-7613(2003)031<0501:PIPOCD>2.0.CO;2

XiaO, S.H., Zhang, Y. \& Knoll, A.H. 1998. Three-dimensional preservation of algae and animal embryos in a Neoproterozoic phosphorite. Nature 391, 553-558. DOI 10.1038/35318

Yin, Z.J. \& ZHU, M.Y. 2012. New observations of the ornamented Doushantuo embryo fossils from the Ediacaran Weng'an Biota, South China. Bulletin of Geosciences 87(1), 171-181. DOI 10.3140/bull.geosci.1234

VAughan, A.P.M. \& PANKhURST, R.J. 2008. Tectonic overview of the West Gondwana margin. Gondwana Research 13, 150-162. DOI 10.1016/j.gr.2007.07.004

Weber, B., Hu, S.X., Steiner, M \& Zhao, F.C. 2012. A diverse ichnofauna from the Cambrian Stage 4 Wulongqing Formation near Kunming (Yunnan Province, South China). Bulletin of Geosciences 87(1), 71-92.

DOI 10.3140/bull.geosci.1239

Zhao, Y.L., Yuan, J.L., Zhang, Z.H., Huang, Y.Z., Chen, X.Y. \& Zноu, Z. 1996. Composition and significance of the Middle Cambrian Kaili Lagerstätte in Taijiang County, Guizhou Province, China: a new Burgess type Lagerstätte. Guizhou Geology 13, 7-14. [in Chinese] 